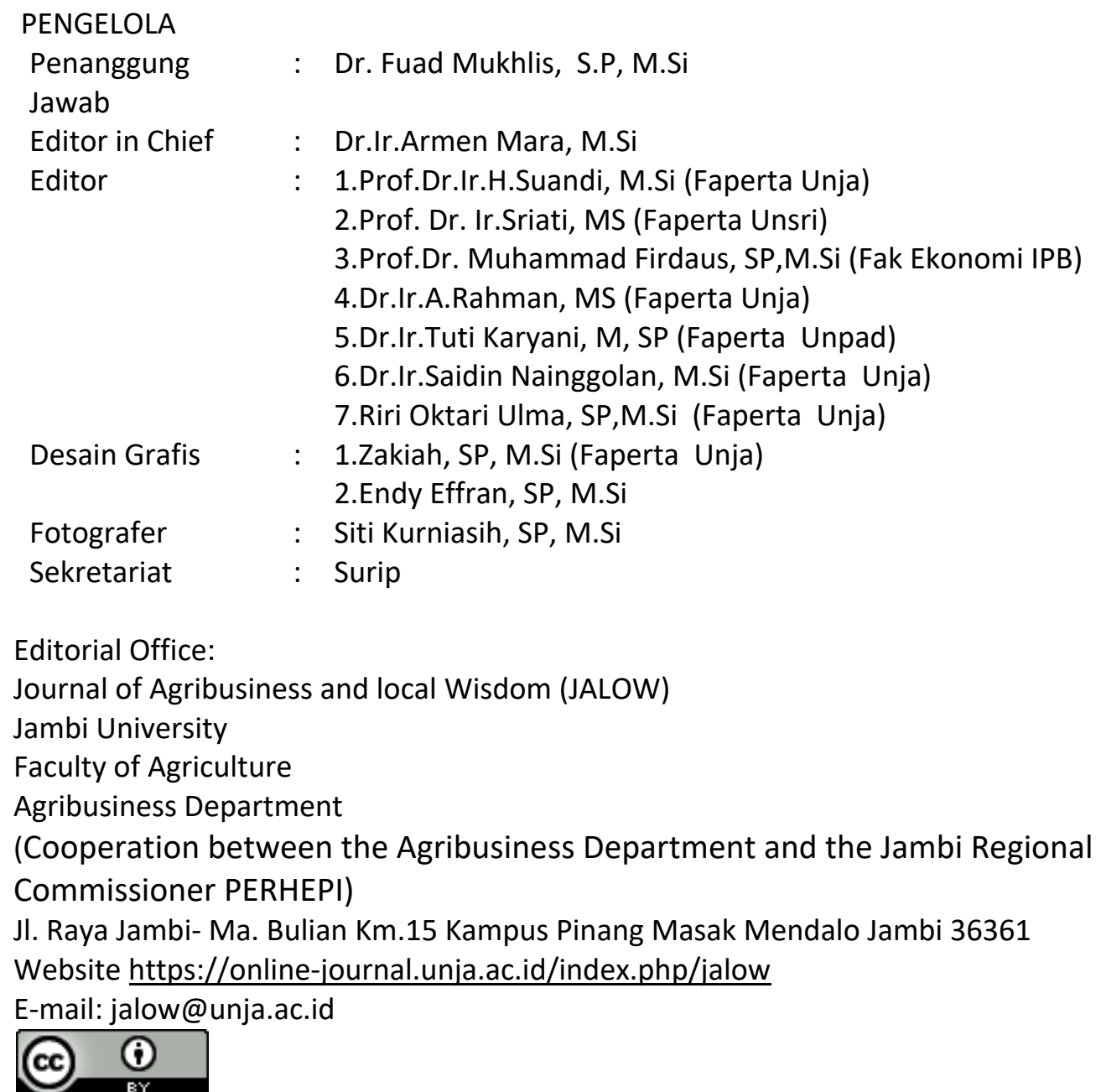

This work is licensed under a Creative Commons Attribution 4.0 International License. 


\section{Assalamualaikum wbwb}

\section{PENGANTAR}

Kondisi agribisnis tahun 2020 ini agak berbeda dengan tahun sebelumnya. Kebijakan penanggulangan Covid19 seperti "dirumah Aja, lockdown lokasi, Isolasi Mandiri, PSBB (Pembatasan Sosial Berskala Besar), dan Herd Immunity" telah merubah pola aktivitas masyarakat, khususnya di Kota-kota. Sebelumnya, berkejar2an dengan waktu untuk meningkatkan pendapatan dengan jalan menambah produktivitas dan menekan biaya telah dikagetkan oleh adanya ancaman pandemi Covid19 yang ada dimana-mana, semangat berkejar-kejaran tersebut kendur seketika.

Kegiatan perdagangan di Kota-kota besar maupun kota kecil telah mengalami kelesuan untuk semua lapisan, mulai dari pedagang kecil mikro, pedagang asongan atau gerobak, pedagang toko, mini market sampai perdagangan berskala besar, super market, dan mallmall. Hal ini menyebabkan terjadinya pengangguran, berkurangnya pendapatan masyarakat dan menurun drastisnya penerimaan pemerintah dari pajak. Selama masa isolasi, para konsumen melakukan belanja dengan sangat hati-hati. Pihak produsen merasakan berkurangnya permintaan. Oleh karena itu, walaupun kebijakan Covid19 tidak menghambat aktivitas produksi pertanian di lahan secara langsung namun karena permintaan berkurang maka berkurang pula pendapatan petani yang mengusahakan kebun atau sawah.

Kebiasaan konsumen yang selama ini lebih banyak makan di luar rumah berubah menjadi lebih banyak makan di rumah sendiri, masak sendiri atau pesan antar. Berbelanja yang semula mencari tempat2 yang banyak di kerumuni orang berubah ke tempat yang tidak ada kerumunannya, artinya rasa enak dan harga murah tidak lagi menjadi patokan utama bagi konsumen. Mereka lebih mengutamakan sehat dan terjamin dalam proses pembuatannya. Kesadaran adanya ancaman bahaya serangan Covid19 terhadap nyawa setiap orang telah menyebabkan berubah nya psikologi dan sosial masyarakat. Sebelumnya berpikir materialis dan untung rugi dari setiap kerja, sekarang mulai nampak adanya kepedulian terhadap perintah agama melaksanakan sholat dan bersedekah. Mulai terlihat adanya aktivitas sosial di tengah-tengah kota, ada kegiatan membagikan nasi bungkus kepada kaum duafah dan lapisan bawah, kegiatan membagikan sembako, membagikan ampelop berisi uang kertas, sampai pada aktivitas memberikan tip berupa uang dalam setiap kali berbelanja di pedagang-pedagang kecil.

Harapan untuk semua aktivitas-aktivitas positif tersebut berlangsung tidak sementara tapi menjadi karakter bagi setiap orang. Kalau aktivitas sosial ini terus dipertahankan oleh pelaku yang telah memulai nya tentu akan diikuti juga oleh yang lainnya. Diharapkan juga setiap pelaku agribisnis berskala kecil, baik yang disektor produksi pertanian maupun sektor industri pengolahan dan perdagangan dapat mengantisipasi perubahan prilaku konsumen tersebut dengan perubahan pola produksi yang sesuai sehingga peluang bisnis yang terlepas dari pola sebelumnya dapat ditangkap.

Demikian semoga JALOW untuk penerbitan ini bermanfaat untuk kita semua aamiin ya robbal aalamiin.

Waalaikumsalam wbwb

Editor in Chief

Dr.Ir.Armen Mara,M.Si 
DAFTAR ISI

\begin{tabular}{|c|c|c|}
\hline 1 & $\begin{array}{l}\text { ANALISIS RESPON PENAWARAN KOMODITI KEDELAI } \\
\text { DI KABUPATEN TANJAB TIMUR } \\
\text { Oleh Edison }\end{array}$ & $1-10$ \\
\hline 2 & 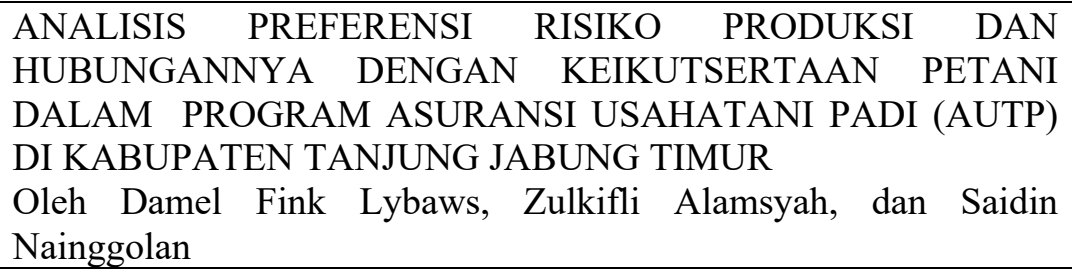 & $11-27$ \\
\hline 3 & $\begin{array}{l}\text { ANALISIS USAHA IKAN HIAS AIR TAWAR DI KOTA JAMBI (ANALYSIS } \\
\text { OF FRESH WATER ORNAMENTAL FISH IN JAMBI CITY) } \\
\text { Dody Hadisaputra, Ernawati, Suandi }\end{array}$ & $28-40$ \\
\hline 4 & $\begin{array}{l}\text { ANALISIS FAKTOR-FAKTOR YANG MEMPENGARUHI PRODUKSI } \\
\text { BOKAR (BAHAN OLAH KARET) DI KABUPATEN BATANGHARI } \\
\text { Oleh Elisabeth Lumban Gaol, Armen Mara, dan Riri Oktari UIma }\end{array}$ & $41-52$ \\
\hline 5 & $\begin{array}{l}\text { ANALISIS PENGAMBILAN KEPUTUSAN UNTUK PEMBELIAN } \\
\text { MAKANAN KEMASAN BERLOGO HALAL MUI (STUDI KASUS IBU } \\
\text { RUMAH TANGGA DI PERUMAHAN AUR DURI DAN PERUMNAS KOTA } \\
\text { BARU, KOTA JAMBI) } \\
\text { Oleh Putri Hana Jusia, Saad Murdy, Lavlinesia }\end{array}$ & $53-66$ \\
\hline 6 & \begin{tabular}{lrrrr} 
STRATEGI & ADAPTASI & PETANI & DALAM & \multicolumn{2}{l}{ MENGHADAPI } \\
RENDAHNYA & HARGA & JUAL & KELAPA & SAWIT DI \\
KECAMATAN & SUNGAI & BAHAR & KABUPATEN & MUARO \\
JAMBI & & & \\
Oleh Fiona Andini & ), Fuad Muchlis $^{2}$ ), Aulia Farida 2) \\
\end{tabular} & $67-73$ \\
\hline 7 & \begin{tabular}{lcllr}
\multicolumn{2}{l}{ KOLABORASI } & DALAM & PENGELOLAAN & \multicolumn{2}{c}{ PERKEBUNAN } \\
KELAPA SAWIT & RAKYAT & (STUDI KASUS: KUD & LUBUK \\
KARYA DAN & KUD & KAMPUNG & SURAU & KAB. \\
DHARMASRAYA & & & & \\
Oleh Yulistriani & & & & \\
\end{tabular} & $74-81$ \\
\hline 8 & $\begin{array}{l}\text { KEPUTUSAN PETANI SAWIT DALAM MENGKONVERSI } \\
\text { LAHAN KELAPA SAWIT MENJADI LAHAN PADI SAWAH DI } \\
\text { KECAMATAN BATANG ASAM KABUPATEN } \\
\text { TANJUNG JABUNG BARAT } \\
\text { Oleh Krielson Ompusunggu1), Arsyad Lubis2, Siti Kurniasih2 }\end{array}$ & $82-88$ \\
\hline 9 & $\begin{array}{l}\text { KAITAN BIAYA DAN TEKNIK PEREMAJAAN } \\
\text { KELAPA SAWIT RAKYAT } \\
\text { Oleh Nur Imdah Minsyah }\end{array}$ & $89-99$ \\
\hline 10 & $\begin{array}{l}\text { STRATEGI RANTAI PASOK KELAPA SAWIT DI PROVINSI } \\
\text { SUMATERA BARAT } \\
\text { Oleh Rahma Dzulqa1*), Rika Ampuh Hadiguna2) }\end{array}$ & 100 \\
\hline
\end{tabular}




\title{
ANALISIS PREFERENSI RISIKO PRODUKSI DAN HUBUNGANNYA DENGAN KEIKUTSERTAAN PETANI DALAM PROGRAM ASURANSI USAHATANI PADI (AUTP) DI KABUPATEN TANJUNG JABUNG TIMUR
} oleh

\author{
Damel Fink Lybaws ${ }^{*}$, Zulkifli Alamsyah ${ }^{* *}$, Saidin Nainggolan ${ }^{* * *}$ \\ ${ }^{*}$ Alumni Program Studi Agribisnis Program Pasca Sarjana \\ ${ }^{* *}$ ) Dosen Program Studi Agribisnis Program Pasca Sarjana \\ Universitas Jambi \\ Email : damelfink@gmail.com
}

\begin{abstract}
Agriculture insurance is offered as one of the funding schemes relating to risk sharing in farming activities. Risk plays as important farmer's decision to use inputs. This study aimed: (I) to describe the implementation o the AUTP Program in Tanjung Jabung Timur district. (II) Identify production factors influence the risk of rice production, (iii) Farmer's preferences in acing the risk in rice production, (iv) the relationship of implementing the AUTP Program with behavior of rice farmers. The production function with Just and Pope model was used to knowing influence the risk of rice production, risk preference of khumbakar model was used to estimate risk of rice production. Chi Square test is used to determine the relationship of the implementation of the AUTP Program with behavior of rice farmers. The data obtain from 95 respondents who selected randomly using (simple random sampling). The research result showed that all factors of production effect field rice farming significantly. Meanwhile, partially the use of factors of production seed, NPK fertilizer, urea fertilizer, labour, and land area affect the production significantly on the risk of wetland rice. The average farmer's preference tend to be risked taker, there is a significant relationship between the farmer participation in the AUTP Program and farmer's preferences in facing the risk of rice production.
\end{abstract}

Keywords : Risk, Production, Preference, Wetland Rice

\section{PENDAHULUAN}

Asuransi pertanian ditawarkan sebagai salah satu skema pendanaan yang berkaitan dengan pembagian risiko dalam kegiatan usahatani. Provinsi Jambi merupakan salah satu tempat dilaksanakan Program Asuransi Usahatani Padi (AUTP). Program ini telah dilaksanakan di sepuluh kabupaten yang ada di Provinsi Jambi. Pada Tahun 2016, sebanyak 10 kabupaten/kota yang ada di Provinsi Jambi mengikuti Program AUTP dengan jumlah anggota poktan peserta definitif Asuransi Usahatani Padi (AUTP) adalah 4.992 orang dengan jumlah luas lahan sebesar 4.124,19 hektar. Kabupaten Tanjung Jabung Timur merupakan kabupaten dengan luas tanam terbesar dalam mengikuti Program AUTP yaitu (sebanyak 36,57 persen) atau sebanyak 4.124,19 hektar dengan jumlah petani peserta definitif Program AUTP sebanyak 1.401 orang petani, banyaknya jumlah anggota poktan yang mengikuti Program AUTP di Kabupaten Tanjung Jabung Timur tidak terlepas dari tingginya tingkat kerusakan /puso yang dialami petani sebagai akibat dari pengkombinasian input-input produksi yang belum efisien.

Kabupaten Tanjung Jabung Timur merupakan kabupaten dengan luas panen dan produksi terluas setelah Kabupaten Kerinci di Provinsi Jambi, akan tetapi juka dilihat 
dari produktivitas padi sawah di kabupaten tersebut masih rendah. Produktivitas usahatani padi sawah di Kabupaten Tanjung Jabung Timur baru mencapai 4,0 ton/ha (produktivitas provinsi 4,7 ton/ha) hal ini menunjukkan bahwa produktivitas padi sawah di Kabupaten Tanjung Jabung Timur masih rendah. Produktivitas yang rendah tersebut berikaitan dengan penggunaan input yang digunakan. Selain itu, salah satu penyebab rendahnya produktivitas usahatani padi sawah di Kabupaten Tanjung Jabung Timur adalah adanya risiko. Beberapa risiko yang sering dihadapi oleh petani padi seperti banjir, kekeringan, serta serangan hama penyakit. Keberadaan risiko tersebut dapat menjadi kendala untuk meningkatkan produktivitas padi, sehingga petani ditutut untuk dapat memanajemen dan mereduksi risiko yang ada dalam kegiatan usahataninya. Hampir di setiap proses produksi, terutama produksi dibidang pertanian, risiko berperan penting dalam membentuk keputusan petani terhadap penggunaan input-input. Keputusan petani dalam alokasi input produksi dipengaruhi oleh preferensi petani terhadap risiko produksi.

\section{METODE PENELITIAN}

Penelitian ini dilakukan di lingkup Kabupaten Tanjung Jabung Timur dengan menggunakan data primer dan data sekunder. Dalam penelitian ini dipilih dua kecamatan yaitu Kecamatan Berbak dan Kecamatan Rantau Rasau dengan pertimbangan bahwa kedua kecamatan tersebut merupakan kecamatan dengan luas areal tanam padi sawah terbesar dalam penerapan Program AUTP di Kabupaten Tanjung Jabung Timur. Data yang dikumpulkan meliputi data primer dan data sekunder. Data primer diperoleh secara langsung melalui wawancara dan pengisian kuisoner terhadap petani sampel. Data sekunder yang diperoleh secara tidak langsung melalui kajian literatur atau studi pustaka dan instansi-instansi terkait yang berhubungan dalam penelitian ini.

Penentuan jumlah sampel dalam penelitian ini digunakan rumus Slovin (Riduwan, 2007), dengan tingkat presisi 10 persen. Jumlah sampel petani sebanyak 95 petani yang kemudian dibagi menjadi 2 sub sampel yaitu 52 petani peserta AUTP dan 43 petani non peserta AUTP. Penentuan jumlah sampel yang diambil dari Kecamatan Berbak dan Kecamatan Rantau Rasau sesuai karakteristik responen tersebut dilakukan pengambilan sampel melalui rumus metode alokasi sampel proporsional.

Dalam penelitian ini metode analisis yang digunakan untuk menjelaskan gambaran usahatani padi digunakan analisis statistik deskriptif. Untuk tujuan kedua yaitu menduga model fungsi risiko Just and Pope. Data-data dan informasi yang diperoleh dari petani selanjutnya akan dianalisis dan regresikan. Fungsi produksi rata-rata varians produktivitas padi sawah adalah sebagai berikut :

LnY $=\beta 0+($ Ln Benih+DX1) $+($ Pupuk NPK+DX2) $+($ Pupuk Urea+DX3 $)+($ Pestisida+DX4) + $($ Tenaga Kerja+DX5) $+($ Luas Lahan+DX6 $)+\varepsilon$

Fungsi variance produktivitas:

Lno2Y $=\theta 0+\theta 1($ Ln Benih+DX1) $+\theta 2($ Pupuk NPK+DX2) $+\theta 3($ Pupuk Urea+DX3) + $\theta 4($ Pestisida+DX4) $+\theta 5($ Tenaga Kerja+DX5) $+\theta 6($ Luas Lahan+DX6 $)+\varepsilon$ 
Variance produktivitas:

$\sigma 2 \mathrm{Y}=\left(\mathrm{Y}^{*}-\hat{\mathrm{Y}} \mathrm{i}\right) 2$

Keterangan :

$\begin{array}{ll}\mathrm{Y} & =\text { Produksi padi sawah }(\mathrm{kg}) \\ \mathrm{X} 1 & =\text { Benih }(\mathrm{Kg}) \\ \mathrm{X} 2 & =\text { Pupuk NPK }(\mathrm{kg}) \\ \mathrm{X} 3 & =\text { Pupuk Urea }(\mathrm{kg}) \\ \mathrm{X} 4 & =\text { Pestisida }(\mathrm{ml}) \\ \mathrm{X} 5 & =\text { Tenaga Kerja (HKSP) } \\ \mathrm{X} 6 & =\text { Luas lahan (Ha) } \\ \sigma 2 \mathrm{Y} & =\text { Variance error produktivitas } \\ \mathrm{Y}^{*} & =\text { Produksi Frontier } \\ Y^{\wedge} & =\text { Produksi Aktual } \\ \varepsilon & =\text { error } \\ \beta, \theta & =\text { Konstanta }\end{array}$

$\beta 1, \beta 2, \ldots, \beta 6=$ Koefisien parameter dugaan $X 1, X 2, \ldots, X 6$

untuk menjawab tujuan ketiga pilihan risiko yang dapat timbul diperoleh dari $\theta$ dan $\lambda$ yang ada dalam persamaan berikut (Khumbakar, 2002):

$\theta=\frac{\left(- \text { AR.g }(x)-\text { DR.g }{ }^{2}(x) \cdot a\right)}{\left(1+\text { AR.g(x).a+0,5DR.g }{ }^{2}(x)+q^{2}(x)\left(\left(b^{2}+a^{2}\right)\right.\right.}$ $\lambda=$ $\frac{\left(a+R \cdot q(x)\left(b^{2}+a^{2}\right)+0,5 D R \cdot g^{2}(x)+q^{2}(x) \cdot\left[a+c+3 a b^{2}+a^{3}\right]\right)}{\left(1+A R \cdot g(x) \cdot a+0,5 D R \cdot g^{2}(x)+q^{2}(x)\left(\left(b^{2}+a^{2}\right)\right.\right.}$

dimana:

$\mu \Pi=f(x, z)-w \cdot x$

$A R=U^{\prime \prime}(\mu \Pi) / U^{\prime}(\mu \Pi)$ adalah ukuran Arrow-Pratt dari absolute risk aversion

$D R=U^{\prime \prime \prime}(\mu \Pi) / U^{\prime}(\mu \Pi)$ adalah ukuran dari downside risk aversion

$\theta \quad=$ Komponen risiko produksi

$\lambda \quad=$ Komponen efisiensi teknis

1. Jika $\theta=0$ dan $\lambda=0$ maka produsen bersifat netral terhadap risiko.

2. Jika $\theta>0$ dan $\lambda>0$ maka produsen bersifat risk taker

3. Jika $\theta<0$ dan $\lambda>0$ maka produsen bersifat risk averter

Untuk menjawab tujuan ke empat untuk mengetahui hubungan dari penerapan program AUTP dengan perilaku petani padi sawah menggunakan Uji Chi Squere $(\chi 2)$ dengan koreksi Yates (Sigel, 2010) sebagai berikut: 
Tabel 1. Analisis Tabel Kontingensi $2 \times 2$

\begin{tabular}{|c|c|c|c|}
\hline \multirow{2}{*}{ Golongan petani } & \multicolumn{2}{|c|}{ Perilaku Petani } & \multirow{2}{*}{ Jumlah } \\
\hline & Risk taker & Risk Averter & \\
\hline Peserta AUTP & $A$ & $B$ & $A+B$ \\
\hline Bukan Peserta AUTP & C & D & $C+D$ \\
\hline Jumlah & $A+C$ & $B+D$ & $\mathrm{~N}$ \\
\hline
\end{tabular}

Uji Chi Square ( $\chi 2$ ) yang digunakan adalah dengan koreksi Yates (Sigel, 2010) sebagai berikut

$$
\mathrm{x}^{2}=\frac{\mathrm{N}\left[(\mathrm{AD}-\mathrm{BC})-\frac{\mathrm{N}}{2}\right]^{2}}{(\mathrm{~A}+\mathrm{B})(\mathrm{C}+\mathrm{D})(\mathrm{A}+\mathrm{C})(\mathrm{B}+\mathrm{D})}
$$

Keterangan : $\mathrm{N}=$ jumlah sampel

\section{HASIL DAN KELUARAN PENELITIAN}

\section{Identitas Petani Sampel}

Petani sampel dalam penelitian ini berjumlah 95 petani padi sawah yang diperoleh dari dua kecamatan, yaitu: Desa Banjar Jaya, Marga Mulya, Rantau Makmur, Pengayut Simpang. Adapun yang menjadi penentu identitas petani sampel didaearah penelitian mencakup umur petani, tingkat pendidikan, pengalaman berusahatani, dan jumlah anggota keluarga. Rata rata umur petani peserta AUTP adalah 47 tahun dengan kisaran umur antara 30 sampai 68 tahun. Rata-rata umur petani non peserta AUTP adalah 42 tahun, dengan kisaran umur antara 23 sampai 65 tahun. Berdasarkan pada tingkat pendidikan formal, sebagian besar petani peserta dan non peserta program AUTP menempuh pendidikan sekolah menengah pertama (SMP). Hal ini menunjukkan tingkat pendidikan petani responden didaerah penelitian masih tergolong rendah. Rata-rata pengalaman usahatani petani peserta AUTP adalah 15 tahun dengan kisaran umur antara 5 sampai 26 tahun. Rata-rata pengalaman usahatani petani non peserta AUTP adalah 16 tahun dengan kisaran umur 4 sampai 40 tahun. Jumlah anggota keluarga sangat berperan dalam pengelolaan usahatani, karena semakin banyak jumlah anggota keluarga maka semakin tinggi kebutuhan yang harus dipenuhi oleh petani dan semakin tinggi tanggung jawab petani untuk memenuhi kebutuhan. Rata rata jumlah anggota keluarga petani peserta dan non peserta AUTP memiliki jumlah anggota keluarga sebanyak empat orang.

\section{Gambaran Umum Pelaksanaan Program AUTP di Daerah Penelitian}

Kegiatan pelaksanaan program AUTP didaerah penelitian mulai dari minat petani, pendaftaran peserta, dan pengajuan klaim. Untuk mengetahui pelaksanaan program 
AUTP maka peneliti melakukan wawancara kepada penyuluh pertanian dan petani didaerah penelitian dengan indikator pertanyaan mengenai ;1) minat petani, (2) pengajuan klaim, (3) pendaftaran peserta. Untuk lebih jelasnya dapat dilihat pada Tabel 2 di bawah ini:

Tabel 2. Distribusi Petani Berdasarkan Potret Pelaksanaan Program AUTP di Daerah Penelitian Tahun 2018

\begin{tabular}{llcc}
\hline \multicolumn{1}{c}{ Kegiatan Program AUTP } & \multicolumn{1}{c}{ Keterangan } & $\begin{array}{c}\text { Jumlah Petani } \\
(\text { KK })\end{array}$ & $\begin{array}{c}\text { Persentase } \\
(\%)\end{array}$ \\
\hline Minat & Pendapat Petani & 64 & 67,37 \\
\multicolumn{1}{l}{ Berminat } & tentang Program & 9 & 9,47 \\
Kurang Berminat & (AUTP) & 22 & 23,16 \\
Pendaftaran Peserta & & & \\
- Sesuai Prosedur AUTP & Proses Pendaftaran & 70 & 73,68 \\
- Tidak Sesuai Prosedur AUTP & Peserta (AUTP) & 25 & 26,31 \\
Pengajuan Klaim & & & \\
Sulit & Proses Pengajuan & 9 & 17,31 \\
Mudah & Klaim AUTP & 43 & 82,69 \\
\hline
\end{tabular}

Tabel 2 menunjukkan bahwa kegiatan program AUTP di daerah peneltian Tahun 2017 rata rata petani berminat meningkuti program AUTP, metode pendaftaran sudah sesuai dengan prosedur dan tergolong mudah. Petani diwajibakan untuk tergabung dalam kelompok tani, kemudian mengisi formulir pendaftaran yang akan didampingi oleh petugas pertanian dan membayar premi ke rekening perusahaan asuransi melalui bank. Total premi asuransi pertanian sebesar Rp. 180.000,-/ha/MT dengan bantuan dari pemerintah sebesar $80 \%$ dari premi yang dibayar oleh petani.

\section{Penggunaan Input Dan Produksi Usahatani Padi Sawah}

Usahatani padi sawah didaerah peneltian umumnya dilakukan petani pada lahan milik sendiri dengan luas lahan berkisar antara 0,45 - 2 ha, dengan luas lahan rata-rata perpetani sebesar 1,31 ha. Kondisi lahan sawahnya adalah lahan pasang surut. Dalam usahataninnya peserta AUTP menggunakan input produksi seperti benih, pupuk urea, pupuk NPK, pestisida dan tenaga kerja dengan rata rata penggunaan secara berurutan yaitu : 39,99 kg/ha, 91,40 kg/ha, 72,39 kg/ha, 338,94ml/ha, dan 70,05 HKSP/ha. Dan petani non peserta AUTP menggunakan input produksi seperti benih, pupuk urea, pupuk NPK, pestisida dan tenaga kerja dengan rata-rata penggunaan secara berurutan yaitu : $36,59 \mathrm{~kg} / \mathrm{ha}, 101,55 \mathrm{~kg} / \mathrm{ha}, 84,09 \mathrm{~kg} / \mathrm{ha}, 281,02 \mathrm{ml} / \mathrm{ha}$, dan 68,73 HKSP/ha. 
Produktivitas padi sawah didaerah penelitian adalah $2588 \mathrm{~kg} / \mathrm{ha}$, dengan tingkat kerusakan estimasi pengajuan klaim program AUTP adalah sebesar 80 persen, sehingga produktivitas dugaannya sebesar $2070 \mathrm{~kg} / \mathrm{ha}$. Rata rata petani didaerah peneltian menjual hasil padi dalam bentuk gabah kering giling dengan rata rata harga 6.800/kg. penerimaan yang diterima petani merupakan perkalian antara jumlah produksi padi dikali dengan harga output, dari hasil tersebut diperoleh bahwa rata-rata jumlah penerimaan yang diterima petani adalah $14.078 .720 \mathrm{Rp} / \mathrm{Ha}$. Berdasarkan hasil tersebut dapat disimpulkan klaim yang ditawarkan program AUTP sebenarnya tidak mampu mencoer kerugian yang diterima petani karena jumlah klaim yang diterima petani jauh lebih rendah yaitu $6.000 .000 /$ hektar.

\section{Fungsi Risiko Just and Pope}

Analisis risiko produksi padi sawah dilakukan dengan menggunakan metode risiko produksi yang telah dikembangkan oleh Just and Pope. Pendekatan analisis risiko produksi dengan metode just and pope ini dapat menggambarkan bagaimana pengaruh input tersebut terhadap risiko produksi yang ditunjukkan dengan pengaruh input terhadap variance produksi. Hasil estimasi ungsi risiko just and pope pada usahatani padi sawah pada Tabel 3 berikut :

Tabel 3. Hasil Estimasi Fungsi Risiko Pada Usahatani Padi Sawah di Kabupaten Tanjung Jabung Timur, 2018

\begin{tabular}{lcccc}
\hline \multicolumn{1}{c}{ Variable } & Coefficient & Std. Error & t-Statistic & Prob. \\
\hline BENIH & -2.861 .319 & 0.465937 & -6.140 .997 & 0.0000 \\
D_Benih & 1.999 .284 & 0.566178 & 3.531 .195 & 0.0007 \\
PUPUK NPK & 0.671937 & 0.218265 & 3.078 .534 & 0.0028 \\
D_Pupuk NPK & -0.600430 & 0.320229 & -1.874 .999 & 0.0644 \\
PUPUK UREA & -1.018 .398 & 0.304258 & -3.347 .147 & 0.0012 \\
D_Pupuk Urea & 0.735686 & 0.368932 & 1.994 .096 & 0.0495 \\
PESTISDA & -0.137023 & 0.271547 & -0.504601 & 0.6152 \\
D_Pestisida & -0.114679 & 0.365072 & -0.314126 & 0.7542 \\
TENAGA KERJA & 1.618 .782 & 0.424053 & 3.817 .408 & 0.0003 \\
DX5_Tenaga Kerja & -1.562 .047 & 0.607804 & -2.569 .984 & 0.0120 \\
LUAS LAHAN & 1.525 .209 & 0.437488 & 3.486 .288 & 0.0008 \\
D_Luas Lahan & -0.930939 & 0.353099 & -2.636 .482 & 0.0100 \\
C & 9.127 .188 & 2.107 .265 & 4.331 .295 & 0.0000 \\
\hline R-squared & 0.454369 & F-statistic & 5.690 .404 \\
Adjusted R-squared & 0.374521 & Prob(F-statistic) & 0.000001 \\
\hline
\end{tabular}

Hasil estimasi fungsi risiko produksi menunjukan nilai $A d j, R^{2}=0,3745$ hal ini bearti sebesar 37,45 \% keragaman risiko produksi mampu dijelaskan secara bersama-sama oleh benih, pupuk NPK, Pupuk urea, pestisida, tenaga kerja dan lahan, sedangkan sisanya 62,55 $\%$ dijelaskan oleh faktor-faktor lain diluar model. Perbedaan sumber risiko relatif sama 
diantara kedua golongan petani dan faktor lain sangat menentukan terjadinya risiko produksi. Hal ini sejalan dengan lahan usahatani pasang surut yang sangat dipengaruhi pasang surut air laut.

Pengaruh penggunaan faktor produksi secara bersama-sama terhadap risiko produksi padi sawah yang dihasilkan dapat diketahui dengan menggunakan uji . dari hasil analisis diperoleh nilai F-statistic sebesar 5,690 dengan probabilitias sebesar 0,0000. Nilai probabilitias yang lebih kecil dari alfa $(0,05)$ menunjukkan hasil yang signifikan. Artinya benih, pupuk NPK, pupuk urea, pestisida, tenaga kerja dan lahan yang terdapat dalam model secara bersama-sama berpengaruh signifikan terhadap risiko produksi. Dengan menggunakan nilai probablitias dapat diketahui variabel independen (faktor produksi) yang berpengaruh signifikan terhadap variance produksi padi sawah. jila nilai probablitias lebih kecil dari 0,05 maka ariabel tersebut berpengaruh signifikan terhadap variance produksi padi sawah. Variabel benih, pupuk NPK, pupuk urea, pestisida, tenaga kerja dan luas lahan berpengaruh nyata terhadap variance produksi padi sawah. Artinya faktor produksi variabel benih, pupuk NPK, pupuk urea, tenaga kerja dan luas lahan berpengaruh nyata terhadap variance produksi padi sawah. artinya faktor produksi benih, pupuk NPK, pupuk urea, tenaga kerja dan luas lahan merupakan actor yang dapat meningkatkan risiko produksi atau menurunkan risiko produksi. Jika terjadi penambahan atau pengurangan pada faktor produksi tersebut akan berpengaruh terhadap variance produksi padi sawah.

Hasil penduga persamaan fungsi variance produksi padi sawah diperoleh bahwa faktor produksi benih (X1) mempunyai nilai probabilitaas $0,0000<\alpha(0,01)$ yang artinya benih berpengaruh sangat signifikan terhadap risiko produksi. Variabel benih mempunyai koefisien parameter negatif $(-2,861)$, artinya semakin banyak benih yang digunakan dalam proses produksi maka risiko produksi padi sawah semakin menurun, sehingga variabel benih merupakan faktor yang mengurangi risik (risk reducing factors). Penambahan benih mendorong penurunan risiko produksi yang diterima petani. Petani dapat memperkecil risiko dengan menurunkan variasi produksi, melalui peningkatan penggunaan benih. Peningkatkan benih yang bermutu sampai pada batas tertentu akan menambah populasi tanaman, sehingga dapat meningkatkan produksi dan akirnya menurunkan risiko produksi. Variabel dummy benih (D_Benih) mempunyai nilai probabilitas sebesar $0,0007<\alpha(0,01)$ yang artinya benih berpengaruh sangat signifikan terhadap risiko produksi. Nilai koefisien parameter dugaan untuk variabel dummy benih (D_Benih) adalah positif $(1,999)$ hal ini menunjukkan bahwa risiko produksi pada petani peserta AUTP lebih besar daripada petani non peserta AUTP, artinya terdapat perbedaan yang signifikan anatara risiko produksi petani padi sawah peserta AUTP dan non AUTP dikarenakan petani peserta AUTP cenderung menggunakan benih yang lebih banyak yaitu sebesar $41,00 \mathrm{~kg} / \mathrm{hda}$ dan petani non peserta AUTP $35,69 \mathrm{~kg} / \mathrm{ha}$. Petani di daerah penelitian menggunakan benih lokal, karena menurut petani daerah penelitian termasuk dataran rendah, sehingga varietas yang digunakan petani hampir sama yaitu benih lokal (temon dan botol). Dari sisi ekonomis benih lokal (botol dan temon) lebih murah dibandingkan benih unggul (ciherang) dan harga benih lokal lebih murah yaitu $4.500 / \mathrm{kg}$ dibandingkan benih unggul yaitu $5.500 / \mathrm{kg}$. selain itu preferensi selera juga ikut 
mempengaruhi dalam hal penggunaan benih, alasan petani menggunakan varietas benih lokal dikarenakan

rasanya yang lebih pulen dibandingkan benih unggul.

Faktor produksi Pupuk NPK (X2) mempunyai nilai probabilitas sebesar 0,0029< $\alpha(0,05)$ yang artinya Pupuk NPK berpengaruh signifikan terhadap risiko produksi. Variabel Pupuk NPK mempunyai koefisien parameter posti $(0,6719)$. Artinya semakin banyak penggunaan pupuk NPK maka akan meningkatkan risiko produksi padi sawah atau merupakan faktor yang meningkatkan risiko. Penelitian ini sejalan dengan penelitian Apriana (2015) menyatakan bahwa variabel pupuk kimia merupakan variabel produksi yang dapat menurunkan risiko produksi. Variabel dummy Pupuk NPK (D_Pupuk NPK) mempunyai nilai probabilitas sebesar $0,0644<\alpha(0,10)$ yang artinya dummy Pupuk NPK berpengaruh signifikan terhadap risiko produksi. Nilai koefisien parameter dugaan untuk variabel dummy Pupuk NPK adalah sebesar $(-0,6004)$. Hal ini berarti bahwa variance produksi padi sawah non peserta AUTP memiliki risiko yang lebih tinggi daripada petani peserta AUTP. Petani non peserta AUTP memiliki risiko yang lebih tinggi daripada petani peserta AUTP. Petani non peserta AUTP menggunakan jumlah pupuk NPK yang lebih besar dibandingkan petani peserta AUTP. Peningkatan penggunaan pupuk NPK ternayta dapat meningkatkan variance produksinya sehingga pupuk NPK dapat meningkatkan risiko produksi. Kelebihan unsur kimia dalam pupuk dapat menyebabkan risiko produksi dan menyebabkan tanaman mengalami keracunan dan mengakibarkan tanaman mati sehingga dapat menurunkan produksi (Aldila,2013).

Faktor produksi pupuk urea (X3) mempunyai nilai probabilitas sebesar 0,0012< $\alpha(0,05)$ yang artinya pupuk urea berpengaruh signifikan terhadap risiko produksi. Variabel pupuk urea mempunyai koefisien parameter negatif(-1,018). Artinya semakin banyak pupuk urea yang digunakan dalam proses produksi maka risiko produksi padi sawah semakin menurun, sehingga variabel benih merupakan faktor yang mengurangi risiko (risk reducing factors). Penelitian ini sejalan dengan penelitian Fanani (2006) menyatakan bahwa variabel pupuk urea merupakan variabel produksi yang dapat menurunkan risiko produksi. Penambahan pupuk urea dapat menyebabkan pengurangan risiko produksi padi sawah. Variabel dummy pupuk urea (D_Pupuk Urea) mempunyai nilai probabilitas sebesar $0,0495<\alpha(0,05)$ yang artinya dummy pupuk urea berpengaruh signifikan terhadap risiko produksi padi sawah di Kabupaten Tanjung Jabung Timur. Nilai koefisien paramerter dugaan untuk variabel dummy pupuk urea adalah sebesar 0,7356. Hal ini berarti bahwa variance produksi padi sawah petani peserta AUTP lebih tinggi daripada petani non peserta AUTP. Hasil analisis statistik menynjukkan bahwa penggunaan pupuk urea secara nyata menurunkan risiko produksi padi sawah, hal ini diduga karena pemakaian pupuk kimia dalam waktu yang lama dan dalam jumlah yang tinggi apabila tidak diimbangi dengan penggunaan pupuk organic akan berdampak terhadap kualitas dan kesuburan tanah. Hal ini sejalan dengan penelitian Suharyanto (2015) bahwa penambahan jumlah pupuk kimia dalam jangka panjang akan meningkatkan produksi dan menurunkan risiko produksi pada usahatani padi.

Faktor produksi pestisida (X4) mempunyai nilai probabilitas sebesar 0,6152 > $\alpha(0,05)$ yang artinya pestisida tidak berpengaruh signifikan terhadap risiko produksi. 
Variabel pestisida mempunyai koefisien parameter negatif $(-1,018)$. Artinya semakin banyak pestisida yang digunakan dalam proses produksi maka tidak akan mempengaruhi risiko produksi. Hal ini sejalan dengan penelitian Aldila (2013) mengemukakan bahwa efisiensi pengendalian OPT sebenanrnya tergantung pada kejadian yang bersifat acak, yaitu ada tidaknya serangan OPT jika tidak ada serangan maka input tersebut tidak akan berpengaruh terhadap produksi. Variabel dummy pestisida (D_Pestisida) mempunyai nilai probabilitas sebesar $0,7542>\alpha(0,05)$ yang artinya dummy pestisida tidak berpengaruh signifikan terhadap risiko produksi. Nilai koefisien parameter dugaan untuk variabel dummy pestisida adalah sebesar $(-0,1146)$. Hal ini bearti bahwa variance produksi padi sawh non peserta AUTP lebih besar daripada petani peserta AUTP. Petani non peserta AUTP memiliki risiko yang lebih tinggi daripada petani peserta AUTP.

Faktor produksi tenaga kerja (X5) mempunyai nilai probabilitas sebesar $0,0003<$ $\alpha(0,01)$ yang artinya tenaga kerja berpengaruh sangat signifikan terhadap risiko produksi. Variabel tenaga kerja mempunyai koefisien parameter positif $(1,618)$. Artinya semakin banyak tenaga kerja yang digunakan dalam proses produksi maka akan mengakibatkan variance produksi padi sawah juga meningkat, sehingga varibael tenaga kerja merupakan faktor yang akan meningkatkan risiko. Penelitian ini sejalan dengan penelitian Suharyanto (2015) yang menyatakan bahwa risiko produksi mengenai penggunaan tenaga kerja tidak berpengaruh nyata terhadap penurunan risiko produksi usahatani padi sawah. variabel dummy tenaga kerja (D_Tenaga Kerja) mempunyai nilai probabilitas sebesar $0,0120<\alpha(0,05)$ yanga rtinya dummy tenaga kerja berpengaruh signifikan terhadap risiko produksi. Nilai koefisien parameter dugaan untuk variabel dummy tenaga kerja adalah sebesar $(-1,562)$. Hal ini berarti bahwa variance produksi padi sawah petani non peseta AUTP lebih tinggi daripada petani peserta AUTP. Variabel dummy tenaga kerja (D_Tenaga Kerja) berpengaruh signifikan terhadap risiko produksi. Petani non peserta AUTP menggunakan jumlah tenaga kerja yang lebih besar dibandingkan petani non peserta AUTP, terdapat perbedaan risiko produksi dalam penggunaan tenaga kerja antara petani peserta dan non peserta AUTP dikarenakan ada beberapa kegiatan dalam prose produksi yang masing jarang dilakukan, terutama kegiatan penyiangan. Petani paling banyak melakukan penyiangan sebanyak 2 kali. Penyiangan seharusnya dilakukan setiap 2 minggu sekali mulai dari umur tanaman 15 HST. Penyiangan ini penting karena untuk mengendalikan populasi gulma. Penggunaan pupuk kimia dapat merangsang pertumbuhan gulma yang tinggi. Jika populasi gulma tinggi maka akan terjadi persaingan antara gulma dengan tanaman padi dalam menyerap hara da air dalam tanah.

Faktor produksi lahan (X6) mempunyai nilai probabilitas sebesar $0,0008<\alpha(0,05)$ yang artinya lahan berpengaruh signifikan terhadap risiko produksi. Variabel lahan mempunyai koefisien parameter postif $(1,525)$. Artinya semakin banyak lahan yang digunakan dalam prose produksi maka akan meningkatkan risiko produksi. Sehingga variabel lahan merupakan faktor yang meningkatkan risiko. Jika penggunaan luas lahan ditambah maka risiko produksi akan meningkat hal ini bisa terhadi karena dengan semakin luas lahan yang digunakan maka akan meningkatakan risiko. Jika penggunaan luas lahan ditambah maka risiko produksi akan meningkat hal ini bisa terjadi karena 
dengan semakin luas lahan yang digunakan maka akan semakin sulit unruk mengendalikan kegiatan usahatani yang dilakukan, dan risiko kegagalan produksi juga akan semakin tinggi. Hal ini sejalan dengan penelitian Apriana (2015) yang mengungkapkan input lahan merupakan input yang risk increasing factor. Penambahan luas lahan yang tidak diimbangi dengan komponen teknologi dalam budidaya padi sawah akan meningkatkan risiko produksi. Variabel dummy lahan (D_Luas Lahan) mempunyai nilai probabilitas sebesar $0,0100<\alpha(0,05)$ yang artinya dummy lahan berpengaruh signifikan terhadap risiko produksi. Nilai koefisien parameter dugaan untuk variabel dummy lahan adalah sebesar $(-0,9309)$. Hal ini berarti bahwa risiko produksi padi sawah petani non pesrta AUTP lebih tinggi daripada petani peserta AUTP. Variabel dummy lahan adalah sebesar $(-0,9309)$. Hal ini berarti bahwa risiko produksi padi sawah petani non peserta AUTP lebih tinggi daripada petani peserta AUTP. Variabel dummy lahan (D_Luas Lahan) berpengaaruh nyata terhadap variance produksi petanin non peserta AUTP memiliki luas lahan yang lebih besar dibandingkan petani non peserta AUTP.

\section{Preferensi Risiko Produksi Petani Padi Sawah}

Hasil analisis fungsi produksi frontier, menunjukkan bahwa risiko produksi digunakan untuk menganalisis preferensi risiko petani padi sawah. berdasarkan hasil analisis preferensi risiko petani padi sawah di Kabupaten Tanjung Jabung Timur pada keseluruhan input produski yaitu benih, pupuk urea, pupuk NPK, obat dan tenaga kerja diperoleh rata rata nilai $\theta$ petani peserta AUTP adalah 0,0160 dan rata-rata nilai $\lambda$ adalah 1,9006 , sedangkan pada usahatani padi non peserta AUTP rata-rata nilai $\theta$ petani adalah $-0,0693$ dan rata-rata $\lambda$ adalah 1,6068 . Hasil ini menunjukkan bahwa rata-rata perilaku risiko petani padi sawah terhadap input-input produksi adalah berani terhadap risiko (risk taker), penelitian ini sejalan dengan penelitian Natasa Apriana (2015) yang menunjukkan bahwa rata-rata preferensi risiko petani adalah risk taker, hasil penelitian ini sejalan dengan penelitian yang dilakukkan di daerah penelitian diperoleh rata-rata preferensi risiko petani keseluruhan (95 sampel) adalah risk taker. Besaran nilai $\theta$ dan $\lambda$ yang dapat dilihat pada Tabel 4.

Tabel 4. Preferensi Risiko Produksi Petani Padi Sawah di Daerah Penelitian, Tahun 2018

\begin{tabular}{lccccc}
\hline & Peserta AUTP & \multicolumn{3}{c}{ Non Peserta AUTP } \\
\hline $\begin{array}{l}\text { Input } \\
\text { Produksi }\end{array}$ & Rata-rata $\theta$ & Rata-rata $\lambda$ & Rata-rata $\theta$ & Rata-rata $\lambda$ & Preferensi \\
\hline Benih & 0,0546 & 2,3428 & 0,1002 & 2,3422 & Risk taker \\
Pupuk Urea & $-0,0428$ & 2,3396 & $-0,5552$ & 2,4466 & Risk Aveter \\
Pupuk Npk & 0,0369 & 2,3431 & 0,0777 & 2,6545 & Risik Taker \\
Pestisida & $-0,0129$ & 2,3518 & $-0,001$ & 2,209 & Risk Aveter \\
Tenaga Kerja & 0,0442 & 0,126 & 0,032 & $-1,6184$ & Risk taker \\
\hline Rata-Rata & 0,016 & 1,9006 & $-0,0693$ & 1,6068 & Risik Taker \\
\hline
\end{tabular}


Preferensi risiko petani terhadap benih adalah risk taker. Petani yang bersifat risk taker akan berani mengalokasikan benih mereka lebih banyak pada usahatani tersebut. Hal ini ditunjukkan dengan rata-rata penggunaan benih yang besar yaitu 38,47 kilogram per hektar, penggunaan benih sebesar itu sudah optimal dan sudah sesuai anjuran dari Kementerian Pertanian (2015) yang menyarankan penggunaan benih dengan menggunakan sistem tabela sebanyak 30-45 kilogram per hektar. Petani padi sawah berani menggunskan benih dalam jumlah yang banyak selain karena ketersediaan benih mudah diperoleh di kios-kios terdekat, ada beberapa petani juga yang dapat memperoduksi benih sendiri. Petani padi sawah berperilaku risk taker terhadap input benih sejalan dengan penelitian Reny Hidayati (2016) diamana preferensi risiko petani terhadap benih adalah menggemari risiko (risk taker).

Perilaku risiko produksi petani padi sawah terhadap input pupuk urea adalah risk aveter atau tidak berani terhadap risiko produksi. Perilaku petani yang risk aveter cenderung menahan penggunaan input tersebut sehingga alokasi penggunaan pupuk urea masih rendah. Hal ini terlihat dari fungsi produksi dan fungsi risikonya, dimana penambahan penggunaan pupuk urea masih bisa meningkatkan produksi dan mengurangi risiko. Perilaku petani yang risk aveter cenderung menahan penggunaan input tersebut. Hal ini terlihat dari fungsi risiko dimana penambahan pupuk urea bisa meningkatkan risiko produksi. Petani padi sawah berperilaku risk aveter terhadap pupuk urea bisa meningkatkan risiko produksi. Petani padi sawah berperilaku risk aveter terhadap pupuk urea karena pemakaian pupuk kimia dalam waktu yang lama dan dalam jumlah yang tinggi apabila tidak diimbangi dengan penggunaan pupuk organic akan berdampak terhadap kualitas dan kesuburan tanah. Penelitian ini sejalan dengan penelitia yang dilakukkab oleh Nurhapsa (2013) yang menunjukkan bahwa petani berperilaku risk aveter terhap pupuk urea.

Perilaku riisko produksi petani padi sawah terhadap input Pupuk NPK adalah risk taker. Petani berani mengalokasikan pupuk NPK karena Pupuk NPK terstandar baik dari sisi komposisi maupun manfaat dari pupuk tersebut. Petani cenderung berani mengalokasikan Pupuk NPK terlihat dari hasil estimasi fungsi risiko produksi, dimana penggunaan Pupuk NPK menyebabkan peningkatan risiko produksi padi sawah. preferensi risiko petani padi sawah terhadap input pestisida adalah risk aveter atau menghindari risiko. Dengan kata lain, petani padi sawah cenderung sedikit menggunakan pestisida. Hal ini ditunjukkan oleh tingkat penggunaan pestisida yang masih sedikit. Petani mengetahui efek dari penggunaan pestisida dalam jumlah yang lebih banyak akan berisiko pada tanaman, sehingga berperilaku risk aveter. Penelitian ini sejalan dengan penelitian yang dilakukan oleh Nurhapsa (2013) yang menunjukkan bahwa petani berperilaku risk averse terhadap insektisida cari.

Preferensi risiko petani padi sawah terhadap tenaga kerja adalah risk taker. Dengan kata lain, petani cenderung mengalokasikan tenaga kerja yang lebih banyak. Petani padi sawah cenderung berani menggunakan tenaga kerja karena usahatani padi sawah merupakan usahatani yang membutuhkan tenga kerja lebih banyak. Disamping itu, ketersediaan tenaga kerja dalam keluarga juga mendukung penggunaan tenaga kerja lebih banyak. Petani padi sawah berperilaku risk taker terhadap input tenaga kerja 
sejalan dengan penelitian Reny Hidayati (2016) dimana preferensi risiko petani terhadap tenaga kerja adalah risk taker.

\section{Hubungan Perilaku Petani Dengan Program AUTP di daerah Peneltian}

Komponen preferensi merupakan kecenderungan beperilaku yang ada didalam diri seseorang berkaitan dengan objek sikap yang dihadapinya. Preferensi ini mengarahkan kepada kemauan petani dalam penerapan Proogram AUTP. Berikut hasil penelitian yang dilakukan mengenai hubungan komponen perilaku petani dengan penerapan Program AUTP di Kabupaten Tanjung Jabung Timur, dapat dilihat pada Tabel 5 berikut:

Tabel 5. Kontingensi Antara Perilaku Petani Dalam Program AUTP di daerah Peneltian, Tahun 2018

\begin{tabular}{lccc}
\hline \multirow{2}{*}{ Golongan Petani } & \multicolumn{2}{c}{ Perilaku Petani } & \\
\cline { 2 - 3 } & Risk taker & Risk Aveter & Jumlah \\
\hline Peserta AUTP & 45 & 7 & 52 \\
Bukan Peserta AUTP & 9 & 34 & 43 \\
\hline Jumlah & 54 & 41 & 95 \\
\hline
\end{tabular}

Berdasarkan uji statistik non parameterik dengan menggunakan uji Kai Square diperoleh nilai nilai $\chi^{2}{ }_{\text {hit }}=38,66$ dan nilai dari $\chi_{\text {tabel }}^{2}=(\alpha=5 \% \mathrm{db}=1)=3,841$, maka keputusannya terima $\mathrm{H}_{1}$ tolak $\mathrm{H}_{0}$ yang artinya terdapat hubungan antara keikutsertaan petani dalam Program AUTP dengan preferensi petani terhadap risiko produksi usahatani padi sawah di Kabupaten Tanjung Jabung Timur. derajat kontingensi keikutsertaan petani dalam Program AUTP dengan preferensi petani terhadap risiko adalah $\mathrm{C}_{\text {hit }}=0,53$ dan $\mathrm{C}_{\text {maks }}$ $=0,70$. Artinya, kecenderungan antara keikutsertaan petani dalam Program AUTP dengan preferensi petani terhadap risiko produksi tergolong kuat dimana $C_{\text {hit }}=0,52$ (berada antara 0,353-0,707). Sedangkan pengukuran derajat korelasi antara keikutsertaan petani dalam Program AUTP dengan preferensi petani terhadap risiko juga diperoleh $r=0,75$. Hasil penguji koefisien $r$ diperoleh $t_{\text {hit }}=10,93>$ dari $t_{\text {tabel }}=(\alpha / 2=5 \%)(d b)=93=1,662$, maka terima $\mathrm{H}_{1}$. Artinya terdapat hubungan yang nyata antara keikutsertaan petani dalam Program AUTP dengan preferensi petani terhadap risiko produksi usahatani padi sawah di Kabupaten Tanjung Jabung Timur pada tara kepercayaan 95\%.

\section{KESIMPULAN}

Pelaksanaan Program AUTP di Kabupaten Tanjung Jabung Timur sudah sesuai dan berjalan dengan baik serta memberikan manfaat perlindungan kepada petani dalam bentuk bantuan modal kerja jika terjadi kerusakan tanaman akibat risiko produksi usahatani. Hasil regresi diperoleh bahwa faktor-faktor produksi pada usahatani padi sawah secara bersama-sama-sama berpengaruh terhadap risiko produksi. Sementara secara parsial hasil regresi diperoleh bahwa penggunaaan faktor produksi benih, pupuk NPK, pupuk urea, tenaga kerja dan lahan berpengaruh signifikan terhadap risiko produksi. Perilaku petani di daerah penelitian adalah risk taker atau Menggemari risiko akan 
semakin berani mengalikasikan input produksi sehingga produksi yang dicapai semakin tinggi. Kombinasi penggunaan input-input pada produksi padi sawah akan mempengaruhi variasi produksi padi sawah yang dihasilkan di daerah penelitian. Terdapat hubungan yang signifikan antara keikutsertaan petani dalam program AUTP dengan preferensi petani terhadap risiko produksi padi sawah di Kabupaten Tanjung Jabung Timur.

Perlu dikaji lebih mendalam mengenai perhitungan klaim yang ditawarkan program AUTP berdasarkan hasil penelitian menunjukkan bahwa jumlah klaim yang ditawarkan tidak mampu mencover kerugian yang dialami petani dengan syarat estimasi kerusakan diatas 75 persen. penggunaan pupuk urea masih bisa ditambah untuk mencapai kestabilan produksi sehingga dapat mengurangi risiko produksi. Selain itu penambahan jumlah pupuk juga diiringi dengan tata kelola air mengingat lahan usahatani di daerah penelitian adalah usahatani pasang surut. Peningkatan produksi padi sawah pada petani bukan peserta AUTP dapat dilakukan dengan cara mereduksi perilaku risk aveter bergabung dalam kelompok tani.

\section{DAFTAR PUSTAKA}

Aldila, Haris Fotari, 2013. Analisis Faktor Faktor Yang Mempengaruhi Risiko Produksi Jagung Manis (Zea Mays Saccharata) Di Desa Gunung Malang Kecamatan Tenjolaya Kabupaten Bogor. Skripsi (Dipublikasikan). Fakultas Ekonomi Dan Manajemen, Institut Pertanian Bogor, Bogor.

Apriana, Natasa, Anna Fariyanti dan Burhanuddin. 2017. Preferensi Risiko Petani Padi Di Daerah Aliran Sungai Bengawan Solo, Kabupaten Bojonegoro, Provinsi Jawa Timur. Jurnal. Program Studi Agribisnis, Sekolah Pascasarjana, Institut Pertanian Bogor, Bogor. Diunduh dari

https://www.researchgate.net/publication/319188493_Preferensi_Risiko_Petaniadi_di_ Daerah_Aliran_Sungai_Bengawan_Solo_Kabupaten_Bojonegoro_Provinsi_Jwa_Tmur. (Diakses pada tanggal 29 April 2019).

Hidayati, R. 2015. Analisis Preferensi Risiko Petani Pada Usahatani Kubis Organic Di Kecamatan Baso Kabupaten Agam Sumatera Barat. Jurnal (Dipublikasikan). Program Studi Ekonomi Pertanian Bogor. Bogor. Diunduh https://journal.ipb.ac.id/index.php/jagbi/article/view/15693. (Diakses pada tanggal 28 April 2019).

Kementerian Pertanian. 2015. Panduan Teknologi Budidaya Padi Tanam Benih Langsung Tabela. Balai Penelitian dan Pengembangan Pertanian Kementerian Pertanian. Jakarta.

Kumbhakar, C.S. 2002. Spesification and Estimation of Production Risk, Risk Preference and Tehnical Efficiency. American Journal of Agricultural Economics, 84(1) : 8-22.

Nurhapsa. 2013. Analisis Efisiensi Teknis Dan Perilaku Risiko Petani Serta Pengaruhnya Terhadap Penerapan Varietas Unggul Pada Usahatani Kentang Di Kabupaten Enrekang Provinsi Sulawesi Selatan. Tesis (Dipublikasikan). Ilmu Ekonomi Pertanian. Program Pasca Sarjana Institut Pertanian Bogor, Bogor.

Riduwan. 2007. Rumus dan Data Dalam Analisis Statistika. Alfabeta. Bandung 
Suharyanto., Rinaldy,J., Arya, N. 2015. Analisis Risiko Produksi Usahatani Padi Sawah Di Provinsi Bali. Jurnal. Balai Pengkajian Teknologi Pertanian Bali. Bali. Diunduh dari http://journal.umy.ac.id/index.php/ag/article/view/1117. Diakses pada tanggal 4 Mei 2019. 